\title{
CARD15 Gene 3020insC Mutation with Inflammatory Bowel Diseases Patients in the Black Sea Region of Turkey
}

\author{
Ilhami Gok ${ }^{1^{*}}$, Fahri Ucar ${ }^{2}$, Orhan Ozgur ${ }^{3}$, Altay Celebi $^{4}$, Omer Sentürk ${ }^{4}$, Sadettin Hulagu ${ }^{4}$ \\ ${ }^{1}$ Department of Bioengineering, Faculty of Engineering \& Architecture, Kafkas University, Kars, Turkey; ${ }^{2}$ Departments of \\ Medical Biology \& Genetics, School of Medicine, Akdeniz University, Antalya, Turkey; ${ }^{3}$ Department Internal Medicine, \\ Divisions of Gastroenterology Karadeniz Technical University, Trabzon, Turkey; ${ }^{4}$ Department Internal Medicine, Division of \\ Gastroenterology, School of Medicine, Kocaeli University, Kocaeli, Turkey
}

Citation: Gok I, Ucar F, Ozgur O, Celebi A Sentürk O, Hulagu S. CARD15 Gene 3020insC Mutation with Inflammatory Bowel Disease Patients in the Black Sea Region of Turkey. OA Maced J Med Sci. 2014 Jun 15; 2(2):215-218. http://dx.doi.org/10.3889/oamjms.2014.033

Key words: Inflammatory Bowel Diseases; Card15 Gene Mutation; Black Sea Region population; Turkey.

Correspondence: Dr. İlhami GÖK. Department of Bioengineering, Faculty of Engineering \& Architecture, Kafkas University, 36100 Kars, Architecture, Kafkas University, 36100 Kars, urkey. E-mail:dnzgoki@gmail.com

Received: 07-Apr-2014; Revised: 24-Apr2014; Accepted: 09-May-2014; Online first: 31-May-2014

Copyright: ๑ 2014 Gok et al. This is an open access article distributed under the terms of the Creative Commons Attribution License, which permits unrestricted use, distribution, and reproduction in any medium, provided the original author and source are credited.

Competing Interests: The authors have declared that no competing interests exist.

\section{Abstract}

BACKGROUND: The role of the CARD15 gene 3020insC frameshift mutation in the pathogenesis of inflammatory bowel diseases (IBD) investigated without a definitive conclusion. The incidence of this mutation in Turkish patients with Crohn's disease is not known.

OBJECTIVE: We investigated whether the CARD15/NOD2 3020insC frameshift mutation is a risk factor for patients with inflammatory bowel disease in Black Sea Region population in Turkey.

METHODS: We studied 3020insC mutation of CARD15/NOD2 gene by allele-specific multiplex PCR in 69 patients with IBD (18 Crohn's disease [CD] and 51 ulcerative colitis [UC]) and 101 ethnically matched healthy controls.

RESULTS: CARD15/NOD2 3020insC frameshift mutation was positive in 7/18 (38.8\%), 13/51 $(25.5 \%)$, and $4 / 101(4 \%)$ of $C D, U C$, and healthy control groups, respectively. None of the controls or patients with Crohn's disease and ulcerative colitis was homozygous for this mutations.

CONCLUSION: This study is to investigate a relation between CARD15/NOD2 3020insC frameshift mutation and in patients with IBD in the Turkish Population. C-insertion frameshift mutation is a major contributor to the susceptibility to both $\mathrm{CD}$ and $\mathrm{UC}$, but it is not specific to patients with $\mathrm{CD}$ in Turkish population.

\section{Introduction}

Crohn's disease $(C D)$ and ulcerative colitis (UC) are two main forms of inflammatory bowel diseases (IBD) characterized by chronic inflammation of the digestive tract sometimes associated with an extra digestive inflammation [1]. The incidence of these diseases is higher in developed countries. The origin, etiology, and pathogenesis of IBD have not been fully understood $[1,2]$. In recent years, certain genes were identified in the pericentromeric region of human chromosome 16 (locus IBD1) that increase the susceptibility to inflammatory bowel diseases, both chronic UC and CD. However, the candidate genes did not show a definitive association with this pathology [1,3]. Recent articles proposed a gene on chromosome 16q12, known as CARD15 (NOD2) is possibly responsible for $C D$ [4-8]. Identified nucleotide oligomerisation domain (NOD2) as the IBD gene and recently, the nomenclature of NOD2 has been changed to caspase activating recruitment domain (CARD15). CARD15/NOD2 has a role in inflammatory response to bacterial triggers, especially lipopolysaccharides (LPS), and is expressed exclusively in monocytes and it has structural homology with $\mathrm{R}$ protein which is a class of plant disease resistance gene product [8]. CARD15/NOD2 comprises an amino terminal effector domain, a nucleotide-binding domain and leucine-rich repeats (RRs) and regulates apoptosis and/or nuclear factor (NF)- $\mathrm{KB}$ activation [9]. The C-insertion mutation at nucleotide 3020 (3020insC) in the LRR region results in a frameshift in the $10^{\text {th }}$ LRR followed by a premature stop codon [10]. This truncation mutation is responsible for the inability to activate nuclear factor $(N F)-\kappa B$ in response to bacterial LPS $[10,11]$. 
The frequency of CARD15/NOD2 3020insC frameshift mutation and relationships with IBD in various populations was investigated by researchers and the genetic heterogeneity of $C D$ in different populations was established. Here we studied this frameshift mutation in 69 Turkish patients with IBD (18 CD, 51UC) and 101 healthy control subjects, to identifiy the susceptible gene for Turkish population.

\section{Materials and Methods}

\section{Study patients and control subjects}

We studied 69 unrelated patients $18 \mathrm{CD}$ and 51 UC. The study also included 101 healthy control subjects. These control subjects were without a personal or family history of inflammatory bowel disease. Blood samples were obtained from patients $(\mathrm{n}=69)$ at Kocaeli University Hospital and Karadeniz Technical University Farabi Hospital in Black Sea Region of Turkey. Blood samples were obtained from healthy control subjects $(n=101)$ in same region. The diagnosis of either ulcerative colitis or CD was confirmed by clinical, radiological, endoscopic and histological examination in accordance with Vienna classification (Gasche et al., 2000). Suspicious cases were excluded from the study.

\section{DNA extraction and 3020insC frameshift mutation analysis}

Blood samples were drawn from cases and controls in the fasting state and collected in EDTAtubes (Vacutaine, Becton Dickinson, Meylon, France). DNA was extracted with salting out method [12] from peripheral blood leukocytes using the Pure gene ${ }^{T M}$ DNA extraction kit (GENTRA, Minneapolis, USA). DNA concentrations were measured spectrophotometrically at $260 \mathrm{~nm}$ and stored at $70^{\circ} \mathrm{C}$. All tests were subsequently performed within 3 weeks of collection.

Table 1: CARD15/NOD2 3020insC Frameshift Mutation AlleleSpecific PCR Conditions.

\begin{tabular}{|c|c|c|c|}
\hline $\begin{array}{l}\text { Stock } \\
\text { Concentrations }\end{array}$ & $\begin{array}{l}\text { Final } \\
\text { Conc. }\end{array}$ & $\begin{array}{l}\text { Volume } \\
(25 \mu \mathrm{l})\end{array}$ & Primer Sequences $\left(5^{\prime} \rightarrow 3^{\prime}\right)$ \\
\hline 10XPCR buffer & $1 \mathrm{X}$ & $5,0 \mathrm{ul}$ & \\
\hline $25 \mathrm{mM} \mathrm{MgCl}_{2}$ & $2.5 \mathrm{mM}$ & $1.5 \mu \mathrm{l}$ & \\
\hline 25 mM dNTP Mix & $0.2 \mathrm{mM}$ & $1.5 \mu \mathrm{l}$ & \\
\hline Control-F(100 uM) & $.25 \mathrm{uM}$ & $1.5 \mu \mathrm{l}$ & CTGAGCCTTTGTTGATGAGC \\
\hline Control-R (100 uM) & $1 \mathrm{uM}$ & $1.5 \mu \mathrm{l}$ & TCTTCAACCACATCCCCATT \\
\hline $\begin{array}{l}\text { Allele-specific(wt)-F } \\
(100 \mathrm{uM})\end{array}$ & $1 \mathrm{uM}$ & $1.5 \mu \mathrm{l}$ & CAGAAGCCCTCCTGCAGGCCCT \\
\hline $\begin{array}{l}\text { Allele- } \\
\text { specific(insC)-R(100 } \\
\text { uM) }\end{array}$ & $0.25 \mathrm{uM}$ & $1.5 \mu \mathrm{l}$ & CGCGTGTCATTCCTTTCATGGGGC \\
\hline Patient's DNA & $30 \mathrm{ng} / \mu \mathrm{l}$ & $2 \mu \mathrm{l}$ & \\
\hline $\begin{array}{l}\text { Taq Pol (5U/ul) } \\
\text { Sterile } d d H_{2} \mathrm{O}\end{array}$ & $0.03 \mathrm{U} / \mu \mathrm{l}$ & $\begin{array}{l}1.0 \mu \mathrm{l} \\
13.0 \mu l\end{array}$ & \\
\hline
\end{tabular}

The CARD15/NOD2 3020insC frameshift mutation was genotyped by using allele-specific multiplex polymerase chain reaction (PCR), in $\mathrm{MJ}$ PTC-100 ${ }^{\text {TM }}$ Thermocycler (MJ Research, Inc. USA).The primers required for this method were purchased from Promega. PCR conditions were as follows (Table 1): an initial denaturation for $2 \mathrm{~min}$ at 94 ${ }^{\circ} \mathrm{C}$, then, 35 cycle at $94{ }^{\circ} \mathrm{C}$ for $30 \mathrm{~s}$, at $60^{\circ} \mathrm{C}$ for $30 \mathrm{~s}$, at $72{ }^{\circ} \mathrm{C}$ for $1 \mathrm{~min}$ and final extension at $72{ }^{\circ} \mathrm{C}$ for 10 min (Ogura et al., 2001). The PCR products were detected by agarose gel electropheresis (at $70 \mathrm{~V}, 55 \mathrm{~A}$ for $1 \mathrm{~h}$ ) on $2 \%$ agarose gel containing ethidium bromide and the fluorescent intensity of each band was evaluated with a UV transilluminator. The three genotypes were defined as follows; $300 \mathrm{bp}$, normal homozygous; $200 \mathrm{bp}$ and $300 \mathrm{bp}$ (two band in electropheresis), heterozygous; and only 200 bp, mutant homozygous (Figure 1).

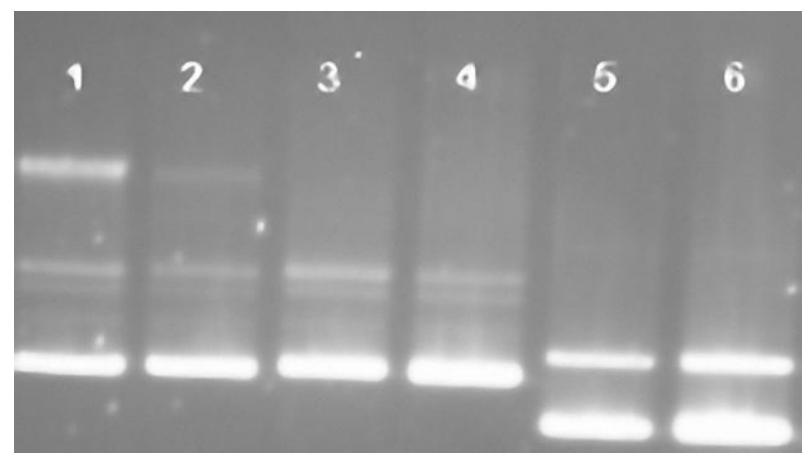

Figure 1: Electrophoresis pattern of CARD15/NOD2 Genes 3020ins C mutation (1-4 Normal. 200 bp and 5, 6 Heterozygous 200/300 bp).

\section{Statistical Methods}

In this study, the statistical analyses were made with the Graphpad Prism 6.02 software. In the evaluation of the data, in addition to the descriptive statistical methods (mean, standard deviation), the $x^{2}$ test was used in the comparison of the patient and control groups and the Fisher reality test was used in the comparisons of the qualitative data. The significance level of $P=0.05$ was taken as basis in the evaluation of the results. In the calculation of the genotypes and allele frequencies, Hardy-Weinberg equality was taken as basis.

\section{Results}

The distribution of CARD15/NOD2 3020insC frameshift mutation in the two groups of patients and control subjects is shown in Table 2.

Table 2: CARD/15NOD2 3020insC frameshift mutation in IBD (UC, CD) and healthy controls in Turkish population.

\begin{tabular}{lllll}
\hline Patients & Wild type & Heterozygote & Homozygote & P value \\
\hline $\operatorname{UC}(n=51)$ & $38(74.6 \%)$ & $13(25.4 \%)$ & 0 & 0.0001 \\
$\operatorname{CD}(n=18)$ & $11(61.1 \%)$ & $7(38.9 \%)$ & 0 & 0.0002 \\
Total IBD $(n=69)$ & $49(71 \%)$ & $20(29 \%)$ & 0 & 0.0001 \\
Controls $(n=101)$ & $97(96 \%)$ & $4(4 \%)$ & 0 & 0.0001 \\
\hline
\end{tabular}

According to allele-specific multiplex PCR results, the frequencyes of this frameshift mutation in Turkish patients were $38.8 \%$ (7 of 18), $25.4 \%$ (13 of 51 ) and $4 \%$ (4 of 101) in CD, UC and healthy subjects, respectively. None of the controls or patients 
with $C D$ and ulcerative colitis was homozygous for these mutations. Significant differences were found in the genotype and allele frequencies of the $\mathrm{C}$-insertion mutation of CARD15/NOD2 gene among patients with IBD (Crohn's disease and ulcerative colitis) and healthy controls $(P<0.05)$. In this study, prevalence of $\mathrm{C}$-insertion mutation of CARD15/NOD2 gene was found to be higher in patients with CD than UC. However, the difference was not significant $(P>0.05)$.

\section{Discussion}

$C D$ and UC are classified as chronic idiopathic inflammatory bowel diseases. The incidence of these diseases is higher in developed countries such as USA, Japan and East European countries and it has increased about twofold in these countries from 1970s to date [13]. Although its etiology and pathogenesis have not been fully understood, result of epidemiological and genetic linkage studies have suggested that IBD is predisposed by certain genetic and environmental factors [14]. The origin of CD is still an enigma in current medicine. In this study, we investigated the association between 3020insC variants and IBD disease using healthy controls. Genomic analyses and statistical association revealed that the mutation in the region is associated with $C D$ and ulcerative colitis among the Black Sea Region population in Turkey. The previous literature has indicated that the rare CARD15/NOD2 3020insC is the risk factor for the $C D$ among different populations [15, 16]. Among the Japanese population however, patients with the CD did not carry the mutants [17]. The frequency of the mutants in the African American patients of CD was found to be lower in comparison to the patients who are Caucasian Americans [18]. The literature indicates that the frequency of mutation varies in different ethnic populations. Therefore, association studies on the frequency of mutation in patients with the $C D$ should target each population individually before any clinical implication [19]. This study is to our knowledge the first attempt to target the IBD patients in the Black Sea population of Turkey and has potential to be applied in the clinical diagnosis. The difference of the mutation frequency in various populations is an important research question. Hence, intensive research has been conducted to tackle the patterns of mutation among various ethnic groups in different continents. The incidence of 3020insC mutation of CARD15/NOD2 in European populations who carry the CD was found to be about $12 \%$ [20-24]. The more detailed analyses among European population revealed that the frequency of the mutation was $16 \%$ among Germans [18, 25], 11.6\% among Italians [21], 9.4\% among British [26, 27] and 10.9\% among Dutch $[23,24]$. In the North America, the reported results indicated that the frequency of the mutation was $8.4 \%$ for Caucasian Americans [25-28], 7.8-8.4\% for Jewish [29] and 1.3-3.7\% among Chinese [30-32]. The prevalence of 3020insC, a frameshift mutation of CARD15/NOD2 gene among the members of Jewish population in various regions who carry $C D$ was found to be around $7.3 \%$ whereas the same mutation was found to be $8.4 \%$ among the members of non-Jewish population [23]. The frequency of the mutation among the Jews who have CD was $8.7 \%$ whereas the frequency was found to be $3.2 \%$ in control group. However, the occurrence of the mutation among nonJewish populations who had CD was $4.3 \%$ and that of control group was about 1.6\% [28]. The elevated number of Crohn alleles could be linked to the effect of prevalence of the mutants [33,34]. In the present study, we found that the frequency of the 3020insC mutant was about $25.4 \%$, which was found to be higher than European populations [30]. Our results are in agreement with the previous literature in which the prevalence of a mutation of 3020ins $C$ was found to be higher among Caucasians who have CD in comparison with European population. This is particularly important since the region we studied is very close to Caucasia. The previous studies have rarely described the mutation in the context of UC [35]. In CD, same mutation 3020insC was studied by some of the groups West of Turkey but their results suggested lower frequnces than in our results [36].

In this study, we found that in addition to $C D$, the frequency of the mutation is very high among the patients of UC. The 3020insC mutation of CARD15 gene has been suggested useful in clinic diagnosis of $\mathrm{CD}$ and UC both of which are IBD. However, we have found the prevalence of mutation to be $25.4 \%$ among patients of CD and \%38.8 among those who are UC.. Based on this result we conclude that this particular mutation may not be suitable as a diagnostic marker to differentiate between the two IBD types at least for the Black Sea region. Investigation of a similar pattern among other populations will be an interesting research venue. Moreover, the genetic heterogeneity of the Anatolian population is not well understood due to paucity of research and more in-depth analyses of linkage between those mutations and IBD has potential for clinic applications.

\section{Acknowledgments}

We are grateful to the Karadeniz Technical University Scientific Research Project unit (Trabzon, Turkey, Grant No: 22.114.001.11) for financially supporting this study.

\section{References}

1. Zhong Y, Kinio A, Saleh M. Functions of NOD-Like Receptors in Human Diseases. Front Immunol. 2013;16(4):333-37.

2. Murillo L, Bart J, Crusius A, VanBodegraven A A, Alizadeh BZ Pena AS. CARD15 Gene and Classification of Crohn's Disease. Immunogenetics.2002;54: 59-61.

3. Crawford NP, Colliver DW, Eichenberger MR, Funke A A, 
Kolodko V, Cobbs GA, Petras RE, Galandiuk S.CARD15 genotype-phenotype relationships in a small inflammatory bowel disease population with severe disease affection status. Dig Dis Sci. 2007;10:2716-24.

4. Hugot JP, Chamaillard M, Zouali H, Lesage S, Cezard JP, Belaiches J. Association of NOD2 leucine-rich repeat variants with susceptibility to Crohn's disease. Nature. 2001; 411: 599603.

5. Ogura Y, Bonen DK, Inohara N, Nicolae DL, Chen FF, Ramos R. A frameshift mutation in NOD2 associated with susceptibility to Crohn's disease. Nature. 2001; 411: 603-06.

6. Lin Z, Hegarty JP, John G, Berg A, Wang Z, Sehgal R, Pastor DM, Wang Y, Harris LR, Poritz LS, Schreiber S, Koltun WA NOD2 mutations affect muramyl dipeptide stimulation of human B lymphocytes and interact with otherIBD-associated genes. Dig Dis Sci. 2013;9:2599-607.

7. Farrel RJ, Peppercorn MA. Ulcerative Colitis. Lancet. 2002; 359: 331-40.

8. Kanaan Z, Ahmad S, Bilchuk N, Vahrenhold C, Pan J, Galandiuk S. Perianal Crohn's disease: predictive factors and genotype-phenotype correlations. Dig Surg. 2012; 2:107-14.

9. Nimmo ER, Stevens C, Phillips AM, Smith A, Drummond HE, Noble CL, Quail M, Davies G, Aldhous MC, Wilson DC, Satsangi J. TLE1 modifies the effects of NOD2 in the pathogenesis of Crohn's disease. Gastroenterology. 2011; 3:972-981.

10. Guo Q S , Xia B, JiangY, Qu Y, Li J. NOD2 3020 insC frameshift mutation is not associated with inflammatory bowe disease in Chinese patients of Han nationality. World $J$ Gastroenterol. 2004;10:1069-71.

11. Gasche C, Scholmerich J, Brynskov J, D'Haens G, Hanauer $\mathrm{SB}$, Irvine EJ. A simple classification of Crohn's disease: report of the Working Party for the World Congresses of Gastroenterology, Vienna 1998. Inflamm Bowel Dis. 2000;6: 815.

12. Rapley R, Walker JM. The Nucleic Acid Protocol Handbook. Humana Press. Ottowa: New Jersey, 2008; 3-29.

13. Cooney $R$, Jewell $D$. The genetic basis of inflammatory bowel disease. Dig Dis. 2009; 4:428-42.

14. Petermann I, Huebner C, Browning BL, Gearry RB, Barclay ML, Kennedy M, Roberts R., Shelling AN, Philpott M, Han DY Ferguson LR. Interactions among genes influencing bacterial recognition increase IBD risk in a population-based New Zealand cohort. Hum Immunol. 2009; 6:440-6.

15. Rigoli L, Romano C, Caruso RA, Lo Presti MA, Di Bella C, Procopio V, Lo Giudice G, Amorini M, Costantino G, Sergi MD, Cuppari C, Calabro GE, Gallizzi R, Salpietro CD, Fries W Clinical significance of NOD2/CARD15 and Toll-like receptor 4 gene single nucleotide polymorphisms in inflammatory bowel disease. World J Gastroenterol. 2008; 28:4454-61.

16. André MF, Aumaître $O$, Piette JC, Grateau G, Cardoso MC Ouchchane L, Kémény JL, Dastugue B, Delpech M, Creveaux I. Analysis of the NOD2/CARD15 gene in patients affected with the aseptic abscesses syndrome with or without inflammatory bowel disease. Dig Dis Sci. 2008;2:490-9.

17. Yamazaki K, Takazoe M, Tanaka T, Kazumori T. Nakamura, Y Absence of Mutation in the NOD2/CARD15 Gene Among 483 Japanese Patient With Crohn's Disease. J Hum Genet. 2002;47: 469-72.

18. Croucher PJ, Mascheretti S, Hampe J, Huse K, Frenzel H, Stoll M. Haplotype structure and association to Crohn's disease of CARD15 mutations in two ethnically divergent populations. Eur J Hum Genet. 2003; 1:6-16.

19. Motamed F, Najafi M, Taghvaei M, Moazzami K, Farahmand F, Khodadad A, Fallahi GH, Parvaneh N, Khatami GR, Rezaei N. NOD2 sequencing in Iranian children with Crohn's disease.

\section{Z Gastroenterol. 2011;12:1526-8}

20. Csillag C, Nielsen OH, Borup R, Olsen J, Bjerrum JT, Nielsen FC. CARD15 status and familial predisposition for Crohn's disease and colonic gene expression. Dig Dis Sci. 2007; 8:1783-9.

21. Giachino D, van Duist MM, Regazzoni S. Analysis of the CARD15 variants R702W, G908R and L1007fs in Italian IBD patients. Eur J Hum Genet. 2004;12: 206-12.

22. Annese V, Palmieri $O$, Latiano $A$, Campieri $M$, Caprilli $R$ Cucchiana S. Frequency of NOD2/CARD15variants in both sporadic and familial cases of Crohn'sdisease across Italy. An Italian Group for Inflammatory Bowel Disease Study. Dig Liver Dis. $2004 ; 36: 121-124$

23. Latiano A, Palmieri O, Corritore G, Valvano MR, Bossa $F$, Cucchiara S, Castro M, Riegler G, De Venuto D, D'Incà R, Andriulli A, Annese V. Variants at the 3p21 locus influence susceptibility and phenotype both in adults and early-onset patients with inflammatory bowel disease. Inflamm Bowel Dis. 2010;16(7):1108-17.

24. Ideström M, Rubio C, Granath F, Finkel Y, Hugot JP. CARD15 mutations are rare in Swedish pediatric Crohn disease. $J$ Pediatr Gastroenterol Nutr. 2005;4:456-1.

25. Hugot JP. CARD15/NOD2 mutations in Crohn's disease. Ann Ny Acad Sci. 2006; 1:9-18.

26. Leung $\mathrm{CH}$, Lam W, Ma DL, Gullen EA, Cheng YC. Butyrate mediates nucleotide-binding and oligomerisation domain (NOD) 2-dependent mucosal immune responses against peptidoglycan. Eur J Immunol. 2009 ;12:3529-37.

27. Abraham $\mathrm{C}$, Cho JH. Functional consequences of NOD2 (CARD15) mutations. Inflamm Bowel Dis. 2006; 7:641-50.

28. 28.Tsianos EV, Katsanos KH, Tsianos VE. Role of genetics in the diagnosis and prognosis of Crohn's disease.World $\mathrm{J}$ Gastroenterol. 2011; 48:5246-59.

29. Cho J.H. Abraham C. Inflammatory bowel disease genetics: Nod2. Annu Rev Med. 2007; 58:401-16.

30. Cucchiara $S$, Latiano $A$, Palmieri $O$, Staiano AM, D'Incà $R$, Guariso G, Vieni G, Rutigliano V, Borrelli O, Valvano MR, Annese V. Role of CARD15, DLG5 and OCTN genes polymorphisms in children with inflammatory bowel diseases. World J Gastroenterol. 2007; 8:1221-9.

31. Linderson $Y$, Bresso $F$, Buentke $E$, Pettersson $S$, D'Amato $M$ Functional interaction of CARD15/NOD2 and Crohn's diseaseassociated TNFalpha-beta polymorphisms. Int $\mathrm{J}$ Colorect Dis. 2005;4:305-11.

32. Leong RW, Armuzzi A, Ahmad T, Wong ML, Tse P, Jewell DP. NOD2/CARD15 gene polymorphisms and Crohn's disease in the Chinese population. Aliment Pharmacol Ther. 2003; 17: 1465-70

33. Cukovic-Cavka S, Vermeire S, Hrstic I, Claessens G, Kolacek S, Jakic-Razumovic J, Krznaric Z, Grubelic K, Radic D, Misak $Z$, Jadresin O, Rutgeerts P, Vucelic B. NOD2/CARD15 mutations in Croatian patients with Crohn's disease: prevalence and genotype-phenotype relationship. Eur $J$ Gastroenterol Hepatol. 2006;18(8):895-9.

34. Leung E, Hong J, Fraser AG, Leung,E, Hong J, Fraser AG. Polymorphisms of CARD15/NOD2 and CD14 genes in New Zealand Crohn's disease patients. Immunol cell biol. 2005;5:498-503.

35. Cukovic-Cavka M, Peña A S. Clinical applications of NOD2/CARD15 mutations in Crohn's disease. Acta Gastroenterol Latinoam. 2007;1:49-54.

36. Tekin F, Berdeli A, Ozutemiz O, Coker A. Evaluation of the association of NOD2/CARD15 gene polymorphisms with clinical course of Turkish Crohn's disease patients. Int J Med Medical Sci. 2009; (5):211-214. 